\title{
Thermal dose and radiation dose comparison based on cell survival
}

\author{
Meredith Lee ${ }^{1 *}$, David Schlesinger ${ }^{2}$, Gail ter Haar ${ }^{3}$, Benjamin Sela ${ }^{1}$, Matt Eames $^{1}$, John Snell ${ }^{1}$, Arik Hananel ${ }^{1}$, \\ Neal Kassell ${ }^{1}$, Jason Sheehan ${ }^{2}$, James Larner ${ }^{2}$, Jean-Francois Aubry ${ }^{4}$ \\ From Current and Future Applications of Focused Ultrasound 2014. 4th International Symposium \\ Washington, D.C, USA. 12-16 October 2014
}

\section{Background/introduction}

The biologic dose response curves of thermal dose and absorbed radiation dose have not been compared to each other even though they have both been extensively investigated separately and combined. Although heat and radiation produce cell kill by different biological mechanisms (Thermal dose denatures proteins and the radiation dose causes DNA damage) a comparison of dose response curves is possible using the endpoint of cell survival.

\section{Methods}

Survival curves for both thermal and radiation doses were extracted for three different types of cells from previously published data. Using models based on the beam shapes of the current clinical systems for the dose profile, the survival curves were generated and the survival profiles were compared for both modalities, Focused Ultrasound (FUS) and Gamma Knife (GK), for a thalamotomy. The thermal dose profile was calculated according to Dewey (1994), from temperature maps simulated with a 3D finite differences time domain code solving the bio-heat equation with a heat deposition term dependent on the pressure field. Radiosurgery dose distributions were exported from the Gamma Knife treatment planning software (Leksell GammaPlan versions 8.0 - 10.1, Elekta $\mathrm{AB}$, Stockholm) with the smallest target as an input.

\section{Results and conclusions}

The comparison showed that focused ultrasound exhibits a steeper dose and survival profile than gamma knife. As shown in Figure 1, a smaller percentage of cells are dead a short distance away from the FUS target compared with GK. Also, cell death drops more gradually for GK

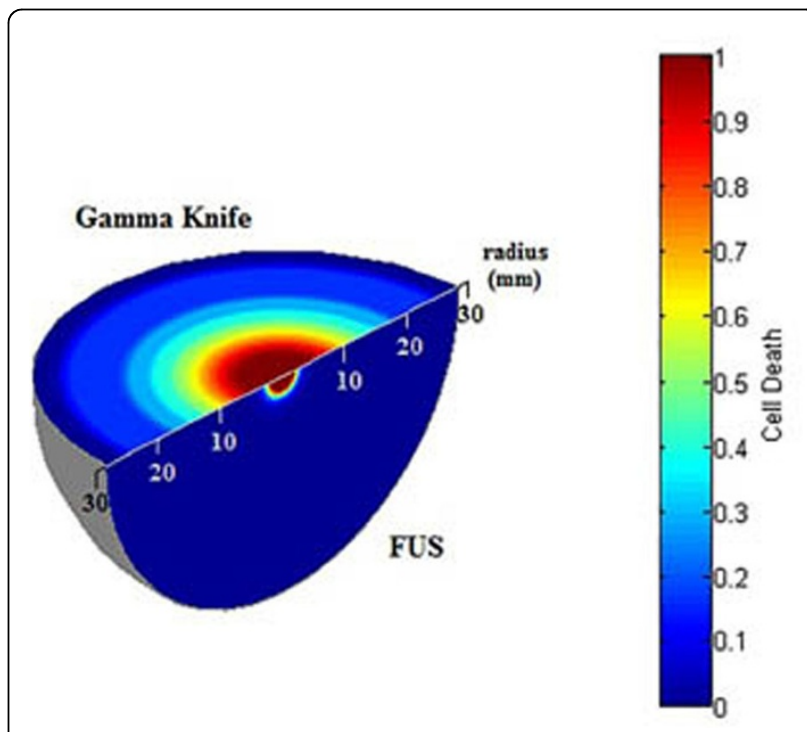

Figure 1 Fraction of cell death radially from the focus of the gamma beams and focused ultrasound beams.

than FUS. Our results establish that the penumbra is steeper for FUS than GK and have implications for making treatment decisions as well as for rationally combing the two modalities.

\section{Acknowledgements (Funding) \\ Focused Ultrasound Foundation}

\section{Authors' details}

${ }^{1}$ Focused Ultrasound Foundation, Charlottesville, Virginia, United States.

${ }^{2}$ University of Virginia, Charlottesville, Virginia, United States. ${ }^{3}$ The Institute of Cancer Research, London, United Kingdom. ${ }^{4}$ Institut Langevin, Paris, France.

${ }^{1}$ Focused Ultrasound Foundation, Charlottesville, Virginia, United States Full list of author information is available at the end of the article 


\section{Reference}

1. Dewey W: Arrhenius relationships from the molecule and cell to the clinic. International journal of hyperthermia 1994, 10(4):457-483.

doi:10.1186/2050-5736-3-S1-P26

Cite this article as: Lee et al:: Thermal dose and radiation dose

comparison based on cell survival. Journal of Therapeutic Ultrasound 2015

3(Suppl 1):P26.

Submit your next manuscript to BioMed Central and take full advantage of:

- Convenient online submission

- Thorough peer review

- No space constraints or color figure charges

- Immediate publication on acceptance

- Inclusion in PubMed, CAS, Scopus and Google Scholar

- Research which is freely available for redistribution 